\title{
HUBUNGAN ANTARA DUKUNGAN SUAMI DAN PARTISIPASI MENGIKUTI KELAS IBU HAMIL DENGAN KECEMASAN MENGHADAPI PERSALINAN PADA IBU HAMIL PRIMIGRAVIDA TRIMESTER TIGA DI PUSKESMAS NGLIPAR II
}

\author{
Nur Fita Romalasari ${ }^{1}$, Kumsih Astuti ${ }^{2}$ \\ Program Studi Magister Psikologi \\ Fakultas Psikologi \\ Universitas Mercu Buana Yogyakarta \\ E-mail: diamoraflo11@gmail.com
}

\begin{abstract}
Abstrak
Penelitian ini bertujuan untuk mengetahui hubungan antara dukungan suami dan partisipasi mengikuti kelas ibu hamil dengan kecemasan menghadapi persalinan primigravida pada ibu hamil trimester tiga di Puskesmas Nglipar II. Sampel penelitian berjumlah 50 ibu hamil. Pengumpulan data menggunakan skala. Analisis data yang digunakan adalah analisis korelasi product moment dan analisis regresi linier berganda. Hasil penelitian menunjukkan bahwa ada hubungan negatif antara dukungan suami dengan kecemasan menghadapi persalinan dengan nilai koefisien korelasi sebesar $\neg 0,331$ dan $\mathrm{p}=0,019(\mathrm{p}<0,05)$. Ada hubungan negatif antara partisipasi mengikuti kelas ibu hamil dengan kecemasan menghadapi persalinan dengan nilai koefisien korelasi sebesar $\neg 0,595$ dan $p=0,000$ ( $p<0,01$ ). Secara bersama-sama ada hubungan antara dukungan suami dan partisipasi mengikuti kelas ibu hamil dengan kecemasan menghadapi persalinan yang berdasarkan nilai $F=6.192$ dan $p=0,004(p<0,01)$. Sumbangan efektif dari dukungan suami dan partisipasi mengikuti kelas ibu hamil secara bersama-sama terhadap kecemasan menghadapi persalinan sebesar 20,9\%, sedangkan sumbangan variabel lain yang tidak diteliti dalam penelitian ini sebesar 79,1\%.
\end{abstract}

Kata Kunci: dukungan suami, partisipasi megikuti kelas ibu hamil, kecemasan menghadapi persalinan

\footnotetext{
Abstract

This research is aiming to understand the relation between husband's support and participation in the class of pregnant women with anxiety facing primigravida labor in pregnant women on third trimester at Puskesmas Nglipar II.. Sample of this research had 50 pregnant women. Rating scale methods used for collecting data. The result of this research showned there are a negative relation between husband's support with anxiety facing childbirth and the correlation coefficient is ᄀ-0,331 with $p=0,019$ ( $p<0,05)$. There are a negative relation between participation in the class of pregnant women with anxiety facing childbirth and the correlation coefficient is $\neg-0,595$ with $p=0,000(p<0,01)$. Stimultaneously there are a relation between husband's support and participation in the class of pregnant women with anxiety facing childbirth based on F score 6,192 and $p=0,004(p<0,01)$. Effective contribution husband's support and participation in the class of pregnant women with anxiety facing childbirth was $20,9 \%$, while the rest $79,1 \%$.
}

Keywords: husband's sipport, participation in the class of pregnant women, anxiety facing childbirth

\section{Info Artikel}

Diterima Februari 2020, disetujui Maret 2020, diterbitkan Juni 2020 


\section{PENDAHULUAN}

Kehamilan bagi seorang wanita merupakan hal yang membahagiakan sekaligus menggelisahkan. Kebahagiaan tersebut karena akan memperoleh keturunan sebagai pelengkap dan penyempurnaan sebagai wanita, namun juga menggelisahkan karena penuh dengan perasaan takut dan cemas mengenai hal-hal buruk yang dapat menimpa dirinya terutama pada saat proses persalinan (Nasir, 2015).

Kehamilan pertama kali bagi seorang calon ibu merupakan suatu perjalanan baru yang ditandai dengan perubahan-perubahan fisik dan psikis sehingga timbul berbagai masalah psikologis.Seorang wanita hamil untuk pertama kali disebut primigravida. Salah satu masalah psikologis yang berpengaruh pada kehamilan adalah kecemasan (Wahyuni, dalam Utami 2011). Munculnya kecemasan pada primigravida (ibu dengan kehamilan pertama kali) salah satunya dipengaruhi oleh perubahan fisik yang terjadi selama kehamilannya. Primigravida tidak terbiasa dengan perut yang semakin membesar dan badan yang bertambah gemuk (Nasir, 2015).

Rasa cemas selama kehamilan dapat timbul akibat kekhawatiran akan proses persalinan yang aman untuk ibu dan bayinya (Utami, 2009). Penyebab lain munculnya kecemasan yang biasa dialami oleh ibu hamil menjelang persalinan antara lain perasaan takut mati ketika melahirkan bayinya, trauma lahir, rasa takut dan nyeri menjelang persalinan terutama bagi calon ibu yang merupakan kehamilan pertama. Menjelang persalinan tingkat stres dan kecemasan ibu semakin meningkat disebabkan karena ibu memikirkan proses persalinan serta kondisi bayi yang akan dilahirkan (Wulandari, 2006).

Kecemasan merupakan gangguan alam perasaan yang ditandai dengan perasaan katakutan dan kekhawatiran yang mendalam dan berkelanjutan, tidak mengalami gangguan dalam menilai realitas, kepribadian masih utuh, perilaku dapat terganggu, tetapi masih dalam batas-batas normal (Jenny, 2013). Menurut Freud (Semiun, 2006) kecemasan merupakan keadaan perasaan afektif yang tidak menyenangkan yang disertai dengan sensasi fisik yang memperingati seseorang terhadap bahaya yang akan datang. Kecemasan pada ibu hamil dalam menghadapi persalinan adalah suatu perasaan takut atau kegelisahan yang muncul sebagai reaksi umum dari ketidakmampuan mengatasi suatu masalah atau tidak adanya rasa aman yang timbul akibat dari perubahanperubahan yang terjadi pada seorang ibu hamil dalam menghadapi persalinan baik 
secara fisik maupun secara psikis. Menurut Maramis (2004), kecemasan dibagi menjadi tiga aspek yaitu fisiologis, psikologis dan kognitif.

Berdasarkan hasil penelitian yang dilakukan Alimah (2016) bahwa ibu hamil trimester III di Puskesmas Banguntapan I mengalami kecemasan ringan sebanyak 31 ibu hamil (64,6\%). Selain itu, pada penelitian Wildan (2016) bahwa dari 53 responden tingkat kecemasan ibu hamil trimester III di RSUD Panembahan Senopati Bantul menunjukkan, tingkat ringan $30,3 \%$, sedang $41,5 \%$, berat $18,9 \%$, dan berat sekali $9,4 \%$.

Dari wawancara pada ibu hamil dalam kelas ibu hamil di Puskesmas Nglipar II pada bulan Oktober 2017, dengan sampel 20 ibu hamil, ada 17 (85\%) ibu hamil mengatakan cemas dalam menghadapi persalinannya dan $3(15 \%)$ mengatakan tidak cemas dalam menghadapi persalinannya. Kecemasan yang dialami ibu hamil ditunjukkan dengan gejala-gejala seperti mengalami sakit kepala, badan terasa pegal, otot tegang, merasa lelah, dan jantung berdebar (aspek fisiologis). Aspek psikologis seperti merasa khawatir, gelisah dan aspek kognitif seperti sulit berkonsentrasi juga dikeluhkan oleh ibu hamil.

Menurut Stuart dan Sundeen (2000), kecemasan menghadapi persalinan dapat dipengaruhi oleh faktor internal dan eksternal. Faktor internal terdiri dari pengetahuan, tahap perkembangan, respon koping, usia, status kesehatan dan fisik, tingkat pendidikan, dan pengalaman masa lalu. Faktor eksternal terdiri dari dukungan sosial dan lingkungan serta nilai budaya dan spiritual.

Faktor pertama yang diangkat dalam penelitian ini adalah dukungan sosial yang lebih difokuskan kepada dukungan suami. Dukungan suami termasuk ke dalam faktor eksternal (berasal dari luar diri individu). Dukungan sosial sangat dibutuhkan bagi ibu hamil terlebih dalam menjelang masa persalinan. Sarafino (2006) menyatakan bahwa dukungan sosial mengacu kepada kenyamanan, perhatian, penghargaan, atau bantuan yang diberikan orang lain atau kelompok kepada individu. Dukungan sosial dapat berasal dari berbagai sumber seperti pasangan hidup, keluarga, kekasih, teman, rekan kerja atau organisasi komunitas. Dukungan sosial yang paling dekat dengan wanita hamil adalah dari pasangannya (suami) (Suryatiningsih, 2007). Dukungan suami adalah dukungan yang diberikan suami terhadap istri, suatu bentuk dukungan dimana suami dapat memberikan bantuan secara psikologis baik berupa motivasi, perhatian dan penerimaan. Dukungan suami merupakan hubungan bersifat menolong dan mempunyai 
nilai khusus bagi istri sebagai tanda adanya ikatan-ikatan yang bersifat positif (Goldberger \& Breznis, 1993). House dan Khan (1995) membagi aspek sosial ke dalam empat aspek. yaitu dukungan emosional, dukungan penghargaan, dukungan instrumental, dan dukungan informatif.

Ibu yang didampingi seorang sahabat atau keluarga dekat (suami) selama proses persalinan berlangsung, memiliki resiko lebih kecil mengalami komplikasi yang mengalami tindakan medis dari pada mereka yang tanpa pendampingan. Dalam penelitian Sosa (2001) ditemukan bahwa kehadiran suami atau kerabat dekat akan membawa ketenangan dan menjauhkan ibu dari stres dan kecemasan yang dapat mempersulit proses persalinan. Kehadiran suami akan membawa pengaruh positif secara psikologis dan berdampak positif pula pada kesiapan ibu secara fisik (Musbikin,2005).

Faktor kedua yang dipilih yaitu partisipasi kelas ibu hamil yang termasuk ke dalam faktor pengetahuan. Pengetahuan termasuk ke dalam faktor internal (berasal dari dalam diri individu). Kurangnya persiapan dan pengetahuan baik si ibu dapat mempengaruhi pikiran dan perasaan ibu hamil dalam menghadapi proses persalinan yang akan memunculkan rasa cemas (Nolan, 2010). Menurut DepKes (2009) Kelas ibu hamil merupakan suatu kegiatan belajar kelompok dalam bentuk tatap muka yang bertujuan untuk meningkatkan pengetahuan dan keterampilan mengenai kehamilan, persalinan, perawatan kehamilan, perawatan bayi baru lahir, mitos dan penyakit.

Kecemasan menghadapi persalinan pada ibu hamil juga dipengaruhi oleh pengetahuan kehamilan yang dimiliki, pengetahuan kehamilan ini dapat diperoleh melalui partisipasi ibu dalam kelas ibu hamil (Nugroho, 2016). Partisipasi adalah keadaan dimana individu, keluarga, maupun masyarakat umum ikut serta bertanggung jawab terhadap kesehatan diri, keluarga, ataupun kesehatan lingkungannya. Dalam suatu masyarakat bagaimanapun sederhananya, selalu ada suatu stimulus. Mekanisme ini disebut pemecahan masalah atau proses pemecahan masalah (Fahmi, 2014). Di sini, partisipasi berarti keikutsertaan ibu hamil dalam program kelas ibu hamil yang dilaksanakan oleh petugas kesehatan.

Kelas Ibu hamil merupakan suatu program dari Kementrian Kesehatan Republik Indonesia sebagai upaya untuk mengurangi angka kematian ibu dan bayi. Kelas ibu hamil merupakan suatu kegiatan belajar kelompok dalam bentuk tatap muka yang 
bertujuan untuk meningkatkan pengetahuan dan keterampilan mengenai kehamilan, persalinan, perawatan kehamilan, perawatan bayi baru lahir, mitos dan penyakit. Kelas ibu hamil mempersiapkan orangtua secara emosional dan psikologis dalam menghadapi masa kehamilan, persalinan, dan juga meningkatkan kepercayaan diri pada ibu. Selain itu kelas ibu hamil meningkatkan pengetahuan, sikap dan keterampilan (Kemenkes,2010 ). Aspek-aspek partisipasi kelas ibu hamil menurut Arsinah (2010) diantaranya adalah keaktifan ibu hamil di dalam kelas, kepatuhan terhadap tata aturan dalam mengikuti kelas, dan frekuensi kehadiran.

Berdasarkan uraian dan hasil wawancara tentang kecemasan ibu hamil dalam menghadapi persalinan maka dapat disimpulkan bahwa penting dilakukan penelitian tentang kecemasan ibu hamil menghadapi persalinan mengingat dampaknya sangat berpengaruh terhadap perkembangan janin selama kehamilan. Kecemasan menghadapi persalinan dianggap faktor risiko terhadap masalah kesehatan mental ibu, seperti meningkatkan kemungkinan depresi pasca melahirkan. Ibu hamil yang baru pertama kali hamil memiliki tingkat lebih tinggi dalam menghadapi kecemasan. Hal ini terjadi karena ia belum ada pengalaman dalam melakukan persalinan (Nugroho, 2016). Oleh karena itu dalam penelitian ini lebih fokus kepada kecemasan yang dialami oleh ibu hamil yang baru pertama kali hamil (primigravida).

Rumusan masalah pada penelitian ini yaitu: (1) Apakah ada hubungan dukungan suami dengan kecemasan menghadapi persalianan pada ibu hamil primigravida? Apakah ada hubungan partisipasi ibu dalam kelas ibu hamil dengan kecemasan menghadapi persalianan pada ibu hamil primigravida? (3) Apakah ada hubungan dukungan suami dan partisipasi ibu dalam kelas ibu hamil dengan kecemasan menghadapi persalianan pada ibu hamil primigravida?

\section{METODE PENELITIAN}

Metode penelitian yang digunakan adalah metode penelitian kuantitatif. Data kuantitatif adalah jenis data yang dapat diukur atau dihitung secara langsung, yang berupa informasi atau penjelasan yang dinyatakan dengan bilangan atau berbentuk angka-angka. Data dikumpulkan oleh peneliti dari sumber pertamanya yaitu ibu hamil. Subjek penelitian adalah ibu hamil primigravida trimester 3 yang mengikuti kelas ibu hamil di Puskesmas Nglipar II. Jumlah subjek sebanyak 50 orang ibu hamil. 
Metode yang digunakan dalam penelitian ini menggunakan metode skala. Metode skala adalah metode yang digunakan untuk mengungkap konstruk atau konsep psikologis yang menggambarkan aspek kepribadian individu ( Azwar, 2013). Pada level ini terdapat dua hal yang dilakukan dalam cara analisis data kuantitatif. Analisis data dalam penelitian ini adalah uji asumsi yang meliputi uji normalitas dan uji linearitas dan uji hipotesis. Pada uji hipotesis digunakan dua analisis yaitu product moment dan regresi linier berganda.

\section{HASIL DAN PEMBAHASAN}

Hipotesis pertama dalam penelitian ini diterima. Hipotesis pertama, mengenai ada hubungan negatif antara dukungan suami dengan kecemasan menghadapi persalinan. Pernyataan pada hipotesis tersebut dapat diterima melalui hasil yang diperoleh dengan menggunakan teknik analisis korelasi product moment. Hasil korelasi yang diperoleh sebesar -0.331 ( $\mathrm{p}<0,05)$. Hasil uji hipotesis tersebut mengandung pengertian bahwa semakin tinggi dukungan suami, maka semakin rendah kecemasan menghadapi persalinan pada ibu hamil. Sebaliknya, semakin rendah dukungan suami, maka semakin tinggi kecemasan menghadapi persalinan pada ibu hamil. Hasil hipotesis ini sejalan dengan penelitian dari Stiarti (2011) yang yang menunjukkan adanya hubungan antara dukungan suami dengan kecemasan menghadapi persalinan pada ibu hamil pramigravida trimester 3 di RSUD Temanggung.

Kehamilan sering menimbulkan kecemasan, rasa takut, bingung dan tidak jarang menimbulkan stress berat, terutama primigravida. Primigravida biasanya mengalami kekhawatiran dan kecemasan yang lebih daripada multigravida. Perubahan psikologis berupa rasa gembira bercampur takut karena kelahiran telah dekat, kecemasan dengan apa yang akan terjadi pada saat melahirkan dan apakah bayi akan lahir sehat (Sukarni, 2013).

Apabila kecemasan sering terjadi sampai periode kehamilan akhir, mengakibatkan kelahiran prematur. Efek tekanan emosi yang berlangsung lama selama masa kehamilan mempengaruhi keseimbangan endokrin, maka kegelisahan dapat terus terbawa sampai periode pascanatal dan mempengaruhi penyesuaian diri pada kehidupan pascanatal. Bayi menunjukkan hiperaktivitas yang akan menghambat penyesuaian pada pola makan, tidur dan baui akan sering menangis (Sukarni, 2013). 
Kepedulian pemerintah dalam menurunkan angka kematian ibu di Indonesia pada tahun 2000 dengan merancangkan Making Pregnancy Saver (MPS) yang merupakan strategi sector kesehatan secara terfokus pada pendekatan dan perencanaan yang sistematis dan terpadu. Salah satu strategi MPS adalah mendorong pemberdayaan perempuan dan keluarga. Ouput yang diharapkan dari stratergi tersebut adalah menetapkan keterlibatan suami dalam mempromosikan kesehatan ibu dan meningkankan peran aktif keluarga dalam kehamilan dan oersalinan (Depkes RI, 2008). Sealain MPS, program lain yang dibentuk oleh pemerintah adalah Gerakan Sayang Ibu (GSI). Program tersebut dibentuk dalam rangka meningkatkan kepedulian suami terhadap ibu hamil, bersalin dan nifas terutama meningkatkan kesadaran suami tentang pentingnya keterlibatan dan dukungan dalam kehamilan istrinya (Kementrian Pemberdayaan Perempuan RI, 2004).

Kurangnya dukungan moral dari keluarga dan suami dapat menyebabkan banyak ibu-ibu hamil merasa khawatir dan takut dalam mengahdapi persalinan sehingga menyebapkan perasaan cemas. Wanita hamil dengan dukungan keluarga khususnya suami yang tinggi akan mengubah respon terhadap sumber kecemasan dan pergi kepada keluarganya untuk mencurahkan isi hatinya (Arifin, 2015).

Salah satu dukungan suami yang ditunjukkan adalah dukungan emosional. Dukungan emosional yaitu sejauh mana individu merasa orang disekitarnya memberikan perhatian, mendorong, serta membantu memecahkan masalah yang dihadapi individu. Perhatian secara emosional yang berupa kehangatan, kepedulian, dan empati yang diberikan oleh suami kepada istrinya selama masa kehamilan akan membuat si ibu merasa nyaman dan memiliki keyakinan bahwa dirinya tidak seorang diri melewati masa-masa kehamilan hingga akhirnya sampai ke masa bersalin (Padila, 2012).

Saat ibu hamil menjalani masa kehamilannya, dukungan lain seperti memberikan semangat (dukungan penghargaan) agar si ibu tetap menjalani hidup sehat dan terus beraktivitas, tidak hanya berdiam diri di rumah saja. Selain itu juga dukungan instrumental seperti suami mengantarkan istri yang sedang hamil kontrol ke puskesmas merupakan bantuan yang sangat berharga untuknya (Padila, 2012).

Uraian di atas menunjukkan bahwa dukungan suami dapat mempengaruhi kecemasan menghadapi persalinan. Hal ini juga sesuai dengan hasil penelitian ini bahwa 
ditemukan adanya hubungan antara dukungan suami dengan kecemasan menghadapi persalinan di Puskesmas Nglipar II. Dukungan suami berada pada kategori sedang dengan jumlah subjek 39 (78\%) dan kategori tinggi berjumlah $11(22 \%)$ sehingga dapat dikatakan para ibu hamil mendapatkan dukungan dari suami selama proses kehamilan mereka. Dukungan suami yang tinggi menurunkan tingkat kecemasan yang dihadapi ibu hamil. Kontribusi variabel dukungan suami terhadap variabel kecemasan menghadapi persalinan $11 \%$ sedangkan $89 \%$ dijelaskan oleh variabel lain yang tidak diukur dalam penelitian ini.

Hipotesis kedua, mengenai adanya hubungan negatif antara partisipasi mengikuti kelas ibu hamil dengan kecemasan menghadapi persalinan. Pernyataan pada hipotesis tersebut dapat diterima melalui hasil yang diperoleh dengan menggunakan teknik analisis korelasi product moment. Hasil korelasi yang diperoleh sebesar -0,595 (p $<0,05)$. Hasil uji hipotesis tersebut mengandung pengertian bahwa semakin tinggi partisipasi mengikuti kelas ibu hamil, maka semakin rendah kecemasan menghadapi persalinan. Sebaliknya, semakin rendah partisipasi mengikuti kelas ibu hamil maka semakin tinggi kecemasan menghadapi persalinan. Hasil hipotesis ini sejalan dengan penelitian dari Wijayanti (2017) yang menemukan hasil bahwa ada hubungan negatif antara keikutsertaan kelas ibu hamil dengan kecemasan menghadapi persalinan.

Perhatian dan perawatan yang baik didapatkan ibu selama kehamilan akan memampukan ibu menghadapi persoalan-persoalan yang dialami ibu. Ibu akan dengan cepat mendapatkan asuhan kebidanan sesuai dengan kebutuhannya seperti penanganan penyulit atau komplikasi dalam kehamilan, sehingga pada saat masa persalinan tiba keadaan umum ibu diharapkan sudah dalam kondisi yang optimal baik fisik maupun psikologis (Sunartyo, 2007).

Kelas Ibu hamil merupakan salah satu kegiatan penting dalam penerapan Buku Kesehatan Ibu dan Anak (KIA) dimasyarakat sebagai upaya pembelajaran ibu, suaminya dan keluarga agar memahami buku KIA melalui metode kegiatan belajar bersama dalam kelas yang di fasilitasi oleh petugas kesehatan untuk mempersiapkan ibu hamil menghadapi persalinan yang aman dan nyaman. Beberapa kegiatan seperti senam ibu hamil, latihan pernafasan pada persalinan dan cara menyusui bayi juga diberikan minat ibu-ibu hamil agar datang mengikuti Kelas Ibu Hamil tersebut (Depkes, 2009). 
Pelaksanaan kelas ibu bermanfaat dalam hal persiapan baik secara fisik maupun psikologis ibu dalam menghadapi persalinan. Dalam segi psikologis kegiatan ibu dapat meningkatkan kepercayaan diri yang cukup dalam menghadapi persalinan. Hal ini terutama diakibatkan karena selama mengikuti kelas hamil peserta diberikan penyuluhan mengenai persalinan, perawatan nifas dan perawatan bayi baru lahir. Penyuluhan yang diberikan kepada ibu hamil memberikan pengetahuan-pengetahuan yang dapat membantu si ibu untuk tetap berpikir rasional. Secara keseluruhan dengan adanya pelaksanaan kelas ibu hamil akan membawa efek yang positif pada ibu hamil dalam proses persiapan kelahiran. Karena dengan mengikuti kelas ibu, ibu hamil mempunyai pengetahuan, keterampilan serta motivasi terkait dengan kesadaran untuk meningkatkan kesehatan ibu dan bayi yang didapatkan selama mengikuti pelajaran pada kegiatan kelas hamil. Hal ini berakibat pada kesiapan mental ibu hamil dalam menghadapi persalinan sehingga akan tercipta keadaan yang tenang, santai, rileks dan nyaman dalam mengahadapi persalinannya (Depkes, 2009).

Uraian di atas menunjukkan bahwa partisipasi mengikuti kelas ibu hamil dapat mempengaruhi kecemasan menghadapi persalinan. Hal ini juga sesuai dengan hasil penelitian ini bahwa ditemukan adanya hubungan antara partisipasi mengikuti kelas ibu hamil dengan kecemasan menghadapi persalinan di Puskesmas Nglipar II. Partisipasi mengikuti kelas ibu hamil berada pada kategori sedang dengan jumlah subjek 18 (36\%) dan kategori tinggi berjumlah 32 (64\%) sehingga dapat dikatakan para ibu hamil rutin mengikuti kelas ibu hamil. Partisipasi mengikuti kelas ibu hamil yang tinggi menurunkan tingkat kecemasan yang dihadapi ibu hamil. Sebaliknya partisipasi mengikuti kelas ibu hamil rendah, maka meningkatkan kecemasan menghadapi persalinan ibu hamil. Kontribusi variabel partisipasi mengikuti kelas ibu hamil terhadap variabel kecemasan menghadapi persalinan $19.2 \%$ sedangkan $80.8 \%$ dijelaskan oleh variabel lain yang tidak diukur dalam penelitian ini.

Hipotesis ketiga mengenai ada hubungan antara dukungan suami dan partisipasi mengikuti kelas ibu hamil dengan kecemasan menghadapi persalinan. Hasil penelitian ditemukan nilai $\mathrm{F}$ hitung sebesar 6.192 ( $\mathrm{p}<0,05)$. Perhitungan dilakukan dengan menggunakan analisis regresi linier berganda dan ditemukan $\mathrm{R}^{2}$ sebesar 0.209. Hasil tersebut mengandung pengertian bahwa secara bersama-sama kedua variabel, yaitu dukungan suami (X1) dan partisipasi mengikuti kelas ibu hamil (X2) memiliki 
hubungan yang signifikan terhadap variabel kecemasan menghadapi persalinan (Y). Semakin tinggi dukungan suami dan semakin tinggi partisipasi mengikuti kelas ibu hamil secara bersama-sama menunjukkan semakin rendah kecemasan menghadapi persalinan. Sebaliknya, semakin rendah dukungan suami dan semakin rendah partisipasi mengikuti kelas ibu hamil secara bersama-sama menunjukkan semakin tinggi kecemasan menghadapi persalinan.

Penelitian yang mendukung hasil temuan penelitian ini adalah dari Arifin (2015). Hasil uji korelasi yang didapat dari penelitian tersebut bahwa ada hubungan antara dukungan keluarga dengan kecemasan menghadapi persalinan. Penelitian lain dari Wijayanti (2015) menunjukkan ada hubungan antara keikutsertaan kelas ibu hamil TM III dengan tingkat kecemasan menghadapi persalinan. Kedua penelitian yang telah disebutkan di atas menandakan bahwa dukungan suami dan partisipasi mengikuti kelas ibu hamil merupakan faktor penting dalam mempengaruhi kecemasan menghadapi persalinan.

Sumbangan dukungan suami dan partisipasi mengikuti kelas ibu hamil dengan kecemasan menghadapi persalinan sebesar 20.9\%. Walaupun sumbangan yang diperoleh hanya 20.9\%, namun hal itu tidak bisa diabaikan mengingat masih cukup banyak faktor yang mempengaruhi kecemasan menghadapi persalinan. Artinya, kedua variabel ini tetap memberi andil yang signifikan dalam hubungannya dengan kecemasan menghadapi persalinan. Sumbangan variabel lain yang tidak diteliti dalam penelitian ini sebesar 71.9\%. Variabel lain yang tidak diikutsertakan dalam penelitian ini dijabarkan sebagai berikut. Pertama, nilai-nilai budaya dan spiritual. Budaya dan spiritual mempengaruhi cara pemikiran seseorang. Kedua, tahap perkembangan. Pada tingkat perkembangan tertentu terdapat jumlah dan intensitas stresor yang berbeda sehingga resiko terjadinya stres pada tiap perkembangan berbeda. Ketiga, respon koping. Mekanisme koping digunakan seseorang saat mengalami kecemasan. Keempat adalah usia. Semakin tinggi usia semakin baik tingkat kematangan emosi seseorang serta kemampuan dalam menghadapi berbagai persoalan. Kelima, kesehatan jiwa dan fisik. Kelelahan fisik dan penyakit dapat menurunkan mekanisme pertahanan alami seseorang. Keenam adalah tingkat pendidikan. Pendidikan rendah pada seseorang akan menyebabkan orang tersebut mudah mengalami kecemasan, semakin tingkat pendidikannya tinggi akan berpengaruh terhadap kemampuan berfikir. Ketujuh, 
pengalaman masa lalu. Pengalaman masa lalu dapat memepengaruhi seseorang dalam menghadapi stressor yang sama (Stuart dan Sundeen, 2000).

\section{KESIMPULAN}

Berdasarkan hasil penelitian yang telah dilakukan dengan menggunakan analisis korelasi product moment dan analisis regresi linier berganda, maka dapat disimpulkan bahwa pada hipotesis pertama, ada hubungan negatif antara dukungan suami dengan kecemasan menghadapi persalinan pada ibu hamil primigravida trimester tiga. Semakin tinggi dukungan suami, maka cenderung semakin rendah kecemasan menghadapi persalinan pada ibu hamil. Sebaliknya, semakin rendah dukungan suami, maka cenderung semakin tinggi kecemasan menghadapi persalinan pada ibu hamil. Dukungan dari suami seperti dukungan emosional, dukungan penghargaan, dukungan instrumental, dan dukungan informatif dapat membantu ibu hamil merasa lebih siap menghadapi persalinan karena dapat menciptakan perasaan aman dan percaya diri karena ia tidak berjuang sendiri dalam menghadapi persalinannya. Pada hipotesis kedua, ada hubungan negatif antara partisipasi mengikuti kelas ibu hamil dengan kecemasan menghadapi persalinan pada ibu hamil primigravida trimester tiga. Semakin tinggi partisipasi mengikuti kelas ibu hamil, maka cenderung semakin rendah kecemasan menghadapi persalinan. Sebaliknya, semakin rendah partisipasi mengikuti kelas ibu hamil, maka cenderung semakin tinggi kecemasan menghadapi persalinan. Ibu hamil yang ikut serta dalam kelas ibu hamil akan mendapatkan pengetahuan-pengetahuan seputar kesehatan dalam menjalani persalinan sehingga hal tersebut membantu si ibu tetap berpikir rasional yang membawa si ibu ke dalam keadaan tenang dan siap menghadapi persalinan.

Pada hipotesis ketiga, ada hubungan antara dukungan suami dan partisipasi mengikuti kelas ibu hamil dengan kecemasan menghadapi persalinan pada ibu hamil primigravida trimester tiga. Semakin tinggi dukungan suami dan semakin tinggi partisipasi mengikuti kelas ibu hamil, maka cenderung kecemasan menghadapi persalinan rendah. Sebaliknya, Semakin rendah dukungan suami dan semakin rendah partisipasi megikuti kelas ibu hamil, maka cenderung kecemasan menghadapi persalinan tinggi. 


\section{DAFTAR PUSTAKA}

Arifin, A., Kundre, R., \& Rompas, S. (2015). Hubungan Antara Dukungan Keluarga dengan Kecemasan Ibu Hamil Menghadapi Proses Persalinandi Puskesmas Budilatama Kecamatan Gadung Kabupaten Buol Propinsi Sulawesi Tengah. Jurnal Keperawatan. 1 (3), 1-6.

Arsinah, S. \& Dewi, S.P. (2010). Asuhan kebidanan masa kehamilan. Graha Ilmu. Yogjakarta.

Astuti, H. (2012). Buku Ajar Asuhan Kebidanan Ibu 1. Jogjakarta: Rohima Press

Astutik, V \& Sutriyani, T (2017). Hubungan Senam Hamil, Dukungan Suami, dan Dukungan Bidan dengan Tingkat Kecemasan Ibu Menjelang Persalinan di BPS NY. HJ. M. Indryati. Jurnal Care. 1 (5), 1-12.

Atkinson. (1993). Pengantar Psikologi. PT Erlangga: Jakarta

Az-Zaghul, I.A. (2003). Kecemasan Menghadapi Masa Persalinan Di Tinjau Dari Keikutsertaan Ibu Dalam Senam Hamil. Jurnal Ilmu Keperawatan dan Kebidanan (JIKK).5 (2), 289-297.

Bobak, M., \& Irene, at. Al. (2005). Buku ajar keperawatan maternitas, edisi 4. Alih bahasa Maria A. Wijayarini. Jakarta: EGC.

Dagun, S.M. (2005). Psikologi Keluarga (Peran Ayah dalam Keluarga). Jakarta: PT Rineka cipta

Daradjat, Z. (1990). Kesehatan Mental. Jakarta: Gunung Agung

Depkes. (2009). Pegangan Fasilitator Kelas Ibu Hamil. Depkes: Jakarta.

Depkes RI. (2008). Asuhan Persalinan Normal. Asuhan Essensial Persalinan. Jakarta: JHPIEGO dan POGI.

Diani, L.P.P. (2013). Pengaruh Dukungan Suami terhadap Istri yang Mengalami Kecemasan pada Kehamilan Trimester Ketiga. Program Studi Psikologi, Fakultas Kedokteran Universitas Udayana. Jurnal Psikologi Udayana. 1 (1), 111.

Diponegoro, A.M. \& Hastuti, S.F.B. (2009). Pengaruh Dukungan Suami terhadap Lama Persalinan Kala II Pada Ibu Primipara. Jurnal Humanitas. 2 (6), 123-135.

Dougall, J. M. (2003). Kehamilan Minggu Demi Minggu. Surabaya: Erlangga.

Eko, H. (2008). Tips Mengatasi Stress Saat Kehamilan. http://www.nusaku.com/forum/archive /index.php/t.4800/24 Juni 2017. Diakses pada tanggal 18 Maret 2018. 
Fahmi, U. (2014). Kesehatan Masyarakat, Teori dan Aplikasi. Jakarta: Rajawali Pres.

Goldberger, L., \& Breznitz, S. (1993). Handbook Of Stress: Theoritical and Clinical Aspect. London: Collier MacMilan Publishers.

House, J., \& Kahn, R.L. (1995). Measures and Concept of Social Support. London: Academic Press Inc.

Jenny J.S.S. (2013). Asuhan Kebidanan Persalinan \& Bayi Baru Lahir. Jakarta: Erlangga.

Johnson, D.W., \& Johnson, F.P. (2012). Dinamika Kelompok Teori dan Keterampilan Edisi Kesembilan. New Jersey: Pearson

Kemenkes RI. (2010). Buku Saku Pelayanan Kesehatan Neonatal Esensial. Jakarta: Departemen Kesehatan.

Kushartanti. (2004). Senam Hamil, Menyamankan Kehamilan dan Mempermudah Persalinan. Yogyakarta: Lingtang Pustaka.

Kusmiyati, Y. (2009). Perawatan Ibu Hamil. Yogyakarta : Fitramaya.

Mahdiyah, D. (2011). Mendampingi Istri Sebuah Tantangan. http:/icuzz.blogspot.com. Diakses pada tanggal 5 April 2018.

Maharani, T. (2014). Hubungan Antara Dukungan Sosial dan Kecemasan dalam Menghadapi Persalinan Pada Ibu Hamil Trimester Ketiga. Jurnal Ilmu Psikologi.7 (2), 61-68.

Maimunah, A., \& Retnowati, S. (2011). Pengaruh Pelatihan Relaksasi dengan Dzikir untuk Mengatasi Kecemasan Pada Ibu Hamil Pertama. Jurnal Psikologi Islam. 8 (1), 1-22.

Mansur, A. (2011). Metode Penelitian dan Teknik Penulisan Laporan Karya Ilmiah. Bandung: PAAP FEB-UNPAD.

Maramis. (2004). Catatan Ilmu Kedokteran Jiwa. Surabaya: Airlangga.

Munandar, U. (2009). Pengembangan Kreativitas Anak Berbakat. Jakarta: Rineka cipta.

Musbikin, I. (2005). Panduan Bagi Ibu Hamil \& Melahirkan. Yogyakarta: Mitra Pustaka.

Nasir, A. ( 2011). Metodologi Penelitian Kesehatan. Yogyakarta: Nuha Medika.

Nevid, J.S. (2005). Psikologi Abnormal. Edisi kelima Jilid 1. Jakarta: Erlangga.

Nolan, M. (2010). Kelas Bersalin. IYogyakarta: Golden Books. 
Nugroho, R.N., \& Cahyanti, R.D. (2017). Hubungan Dukungan Partisipasi Kelas Ibu Hamil terhadap Tingkat Kecemasan Menghadapi Persalinan pada Ibu Hamil Resiko Tinggi. Jurnal Kedokteran Diponegoro. 6 (2), 166-177.

Palupi, F.H. (2012). Perbedaan Tingkat Kecemasan Ibu Primigravida dengan Multigravida dalam Menghadapi Proses Persalinan Kala I di RB Ngudi Saras Jaten Karanganyar. Jurnal Maternal. 6 (1), 68-77.

Prawirohardjo, S. (2008). Ilmu Kebidanan. Jakarta: YBP-SP.

Rose, W. (2007). Panduan Lengkap Perawatan Kehamilan. Jakarta: Dian Rakyat.

Saifuddin A.B. (2006). Buku Acuan Nasional Pelayanan Kesehatan Maternal dan Neonatal. Jakarta: Yayasan Bina Pustaka

Santrock, J.W. (2002). Life-Span Development: Perkembangan Masa Hidup (edisi kelima). (Penerj. Achmad Chusairi, Juda Damanik; Ed. Herman Sinaga, Yati Sumiharti). Jakarta: Erlangga.

Sarafino, E.P. (2006). Health Psychology: Biopsychosocial Interction. Fifth Edition. USA: Jhon Wiley \& Sons.

Sarafino, E.P., \& Timothy, W. S. (2011). Health Psychology Biopsychosocial Interactions Seventh edition. USA: Jhon Wiley \& Sons.

Sarafino, E.P. (2002). Health Psychology Biopsychological Interaction. 2nd ed. USA: John Wiley and Sons Inc.

Sardiman, A.M. (2011). Interaksi dan Motivasi Belajar Mengajar. Jakarta: PT. Rajagrapindo

Sarwono, S.W. (2002). Psikologi Sosial: Individu dan Teori-Teori Psikologi Sosial. Jakarta: Balai Pustaka.

Semiun, Y. (2006). Kesehatan Mental 3. Yogyakarta: Penerbit Kanisius.

Stiarti, D. (2011). Hubungan Dukungan Suami dengan Tingkat Kecemasan Ibu Hamil Pramigravida Trimester 3 di RSUD Temanggung. Jurnal Kesehatan. 12 (3), 115.

Stuart, G.W., \& Sundeen, S.J. (2000). Keperawatan Jiwa (Edisi 5) Cetakan Pertama. Jakarta: EGC.

Sulistyorini, S. (2007). Pengaruh Peran Serta Suami Terhadap Tingkat Kecemasan Ibu Hamil Dalam Menghadapi Proses Persalinan Di Desa Jepat Lor Kecamatan Tayu Kabupaten Pati. Jurnal Psikologi. 1 (1), 1-11. 
Suryosubroto, B. (1997). Proses Belajar Mengajar Di Sekolah. Jakarta: PT. Rineksa Cipta.

Suryatiningsih. (2007). Tips Menghadapi Stres Saat Kehamilan. http://Www.Suryaningsih.Wordpress.Com/2007/05/22/TipsMengatasiStres-

SaatKehamilan/+Dukungan+Sosial+Untuk+Wanita+Hamil. Diakses pada tanggal 2 Mei 2018.

Tzeng, Y.L., Yang, Y.L., Kuo, P.C., Lin, Y.C., \& Chen, S.L. (2017). Pain, Anxiety, and Fatigue During Labor: A Prospective, Repeated Measures Study. Journal of Nursing. 25 (1), 59-67.

Utami, E.R. (2011). Antibiotika, Resistensi, dan Rasionalitas Terapi. Malang: Fakultas Sains dan Tekhnologi UIN Maliki

Wijayanti, I.T., dan Maula, S.I. (2017). Hubungan Keikutsertaan Kelas Ibu Hamil TM III dengan Tingkat Kecemasan Menghadapi Persalinan. Jurnal Maternal. 1 (2), $16-24$.

Wildan, (2016). Hubungan antara Dukungan Suami Selama Kehamilan dengan Tingkat Kecemasan Ibu Hamil Trimester III menghadapi Persalinan di RSUD Panembahan Senopati Bantul Yogyakarta. Jurnal Kesehatan. 3 (2), 12-20.

Wiknjosastro, H. (2007). Ilmu Kebidanan. Jakarta: Yayasan Bina Pustaka

Wiknjosastro, H.. (2008). Ilmu Kandungan. Jakarta: Bina Pustaka.

Wulandari, P.Y. (2006). Efektifitas Senam Hamil Sebagai Pelayanan Prenatal dalam Menurunkan Kecemasan Menghadapi Persalinan Pertama. Jurnal INSAN. 2 (8), 136-142. 